\title{
Collaborative Supply Chain in the Digital Age: A Case Study of its Extent of Adoption by Indigenous Organizations in Building Inter-and Intra-firm Alignments
}

\author{
Hart O. Awa (Corresponding Author) \\ Department of Marketing, University of Port Harcourt \\ P. M. B. 5323, Port Harcourt, Nigeria \\ E-mail: sundayeze@yahoo.com \\ Nsobiari F. Awara \\ Department of Marketing, University of Calabar, Calabar, Nigeria \\ Bartholomew C. Emecheta \\ Department of Management, University of Port \\ Harcourt, P. M. B. 5323, Port Harcourt, Nigeria
}

\begin{abstract}
The term collaborative supply chain or SCM is a social software package that promises inter-and intra-firm alignments and information sharing to assure outstanding performance of the whole. It involves integrating resources and automating transactions across traditional boundaries to build mutually benefiting competitive advantage. SCM in the digital age encompasses accessibility of internal activities and measurement metrics by external parties as well as optimization of processes for mutual improvement in customer service, and reduction of inventory level and associated cost; good business relationships built on trust and minimized selfishness; and long term flexibility and adaptability evidenced by co-creation of products along the value chain. Apparently, experience has shown too many firms avoid engagement in this extensive supply chain integration, perhaps for fear of breeding conflicts. The paper viewed the current practice of SCM by studying the experiences and insights of 108 managers/officers, drawn from eight indigenous firms. The benchmark for selection was that the subject must be directly involved in supply chain initiatives and case study interviews were used for the survey. The finding unravelled discrepancy between the ideals of theories of SCM and actual practice; no consensus about its meaning, multiple supply chain collaboration compounds the problem even the more, and most times it may be difficult to meet the laid down conditions. Firms easily embrace internal cross functional integration and shun inter-organizational integration, perhaps because they want to build unique competitive advantage. Therefore more orientations should be done to educate managers on the ideals of SCM, especially on the area of dissuading selfish maximization of profits.
\end{abstract}

Keywords: Supply chain, Supply chain management, Collaboration, Optimization, Information technology, Innovation, Integration, Network effects

\section{Introduction}

Thomas Friedman's The World is Flat reported that the main effects of the Internet is people learning to adapt to a world where everybody is connected, everyone contributes, and everyone is in zero distance (or close enough) from everyone else (Israel, 2007).

The digital age is right here; everything is revolutionized. Not only has it changed and/or reshaped how the entire enterprise communities communicate and conduct businesses but specifically how the supply chains are operated and managed. The theories of communities of interest/group of companies (Power and Sohal, 2002), collaborative commerce (c-commerce), strategic alliance, B2B (Boone and Kurtz, 2004), social software (McAfee, 2006), enhanced network effects (Koch, 2001), buyer-supplier interface (Humphreys et al, 2006), Vertical Marketing System (VMS) and/or operating system (Ridgeway, 1957) are clear manifestations of the nascent digital force that encourages appropriate inter-firm alignments and relationships to assure outstanding performance. Implicit is that advances in IT are endless (Awa, 2003); they have currently helped supply chains to link their activities into networks enabling them to communicate, collaborate and co-operate through Internet connection (Cook, 2008; Mason et al, 2008). Organizations have relentlessly restructured and re-engineered their processes (Fawcett and Magnan, 2002) often by integrating resources and automating transactions across their traditional boundaries (Ballou et al, 2000; Bartholomew, 1999; Dell 
and Fredman, 1999; Kaplan and Sawhney, 2000) to improve network relationships, to cut costs and create exceptional but difficult to copy customer values (de Burca et al, 2005; Blackwell, 1997).

The objectives and resources of teams of suppliers, finished goods producers, and service providers (transporters and dealers) are integrated to cost-effectively deliver customer value. Abell (1999) opined that this requires the alignment of functional and supply-chain partner activities with company strategy and harmonizing such with organizational structure, processes, culture, incentives, and people. Further, organizations now view markets as social conversation involving participative architecture through which Internet platforms are used to enable online communities (manufacturers, dealers, suppliers, and customers) to relate, to interact and to collaborate. Such social software platforms allow for overtime creativity, communications, secured information sharing in real time, and collaboration between members of on-line communities (McAfee, 2006). Internet-based information transfer attracts more interactivity/interconnectivity built among supply chain partners by replacing traditional supply chain with supply web (Deloitte and Touche, 1998; Kehoe and Boughton, 2001) and by conducting business in a global village (Chou et al, 2004). SCM-related information and decisions are integrated into a complex but well-defined Web of relationships with multiple channels and an open flow of information (Koch, 2001) thereby breaking the old paradigms of inter-organizational boundaries. Supply chains change from an order-driven-lot-sizing approach to one likened to a capacity-availability-booking approach supported by appropriate search engines (Kehoe and Boughton, 2001). The economic potential of this integration in terms of improving both profitability and competitive position was first identified by Forrester (1958) and later operationalized by Wood (1997) and perhaps other theorists who demonstrated that a 10 percent reduction in supply chain's cost structure may yield 40 percent to 50 percent improvement in pre-tax profit.

Collaborative environment permits collaborative structure to determine authority; sharing of risk and rewards; long-term and shared commitment and goals; dividing of cognitive processes into intertwined layers; and mutual participation architectures in a co-ordinated effort to solve a problem. All steps in the supply chain from design to after-sales service are integrated flows (Kennerley and Neely, 2001). Rather than viewing supply chain traditionally (shaving suppliers' margin) (de Burca et al, 2005), the needs of all stakeholders can be best served through more strategic approach of optimization (Power and Sohal, 2002). Networking information for access to all partners in the supply chain provides strong basis for building sustainable competitive advantage (SCA). For instance, Symantec Organization invested in Website containing several bulletin boards, whereupon dissatisfied customers e-mail, or post automatically, their problem(s) to the appropriate bulletin board and expect solution(s) from Symantec's technicians or customer support representatives. Awa (2003) viewed customer satisfaction as not being one-man show, rather it is a complex activity involving inputs from vendors and other independent firms and continues even by the manner the dealers handle and explain customers' complaints and doubts. Such relationship has increasingly attracted primary focus from organization worldwide, perhaps owing to rapid changes in technology, demography, globalization of businesses, product customization, and others, which combine to refocus awareness on optimizing performance based on McCammon and Little's (1965) view of centrally programmed networks rather than individual organizations chasing profit maximization selfishly.

Although technologies such as EDI, barcoding, and product numbering have been in use for over thirty years (particularly EDI) (Johnston and Mak, 2000) to create inter-organizational information flows to the physical movement of goods (Power and Sohal, 2002), Kehoe and Boughton (2001) are of the view that the role of individual organizations in the supply chain need be re-evaluated to reflect current developments in communications and information technologies. Rapid change in technology has positive and negative economic impacts; it provides further opportunities for improved supply chain performance and promotes obsolescence. The Internet, Intranet, and, in particular, the use of Extranet offer opportunity for improvements in supply chain (Kehoe and Boughton, 2001) in order to realize the opportunities of streamlined logistics flows; costs reduction and improved operational efficiencies, typically in procurement, communication, inventory holding, network relationship and search activities (Bakos, 1991; Fernie, 1995; Cottrill, 1997; Chan and Swatman, 2000; Davenport and Brooks, 2004); improved customer service, better quality goods and services and consistency via transparency, value-added information and new levels of innovation from network externalities and knowledge sharing (Raisch, 2001; de Burca et al, 2005).

Despite the apparent opportunities of eSCM; adoption by firms remains slow, especially amongst SMEs. Only a few firms have adopted and disseminated a formal eSCM definition (Fawcett and Magnan, 2002). Many firms show resistance to information sharing for want of building unique competitive advantage. Though much desire to be done, ample research has been done on how eSCM contributes to different business sectors. And therefore the purpose of this paper is to make our humble scholarly contribution in this fascinating area and to specifically report on its current state of adoption in Nigeria. This will provide knowledge on the extent of understanding of how eSCM assists in optimization of the value chain through strategic responses to its challenges. However, this will timely bridge knowledge gap now many Nigeria-based organizations long to re-brand and enhance performance and competitiveness, and to identify the barriers inhibiting them from harnessing the potentials of Internet technologies. 


\section{IT and Change in Supply Chain}

IT brought fundamental changes (Walton and Gupta, 1995; Ferguson, 2000; Koch, 2001) that create competitive advantage in the supply chain (Chou et al, 2004) via cost cutting, bridging of new markets, and protecting of intellectual assets (McKinnon, 2009). Newman and Thomas (2009) noted that IT constantly throws at us new buzz phrases; the thresholds of dramatic shift in ways firms organize, innovate, and create values. The disruptive effects of Internet question tried-and-tested business models, ways of working, organizational structures, and accepted truths (Stamer, 2008) and fundamentally changes the rules of the game since the said changes are exponential (Stamer, 2008; Mancini, 2009). The effects of Internet on supply chain and supply chain management are evident in their operation, at least to the extent of transparency and information visibility. Given that recent states of art may become outdated legacy quite early (Hewitt, 1999; Froehlich et al, 1999), at least for now and in the near future, Internet technology permits optimization of the entire supply chain through inventory cost reduction, total cycle time compression and accessibility of demand data and supply capacity data (Kehoe and Boughton, 2001) for informed decision. The Internet changes how supply chain is managed, planned, and controlled.

\subsection{Supply Chain and Supply Chain Management (SCM)}

The term supply chain has varying connotations ranging from cross-functional process integration within the firm, backward integration with valued first-tier suppliers, and forward integration with valued first-tier customers, to complete forward and backward integrations (Fawcett and Magnan, 2002). Whichever way, confusion still besieges its meaning and definition, perhaps because of its expanding scope and differences in functional views. Its common focus rests on demand and supply planning and forecasting, manufacturing scheduling, and transportation planning though uncommon focus rests on graphical supply chain modeller and supply chain optimizer. Supply chain encompasses all activities associated with the flow and transformation of goods from the raw materials stage (extraction), through to the end user(s) as well as all information flows (Handfield and Nichols, 1999). The bottom line is the creation of mutual values requiring not only managing materials integrated into the flows across enterprise traditional boundaries but also relationships and information in order to minimize conflicts.

This definition contrasts Supply Chain Management (SCM), which is frequently associated with materials management environment as effort to align objectives and integrate resources across company boundaries to deliver greater values. Du (2007) and Fawcett and Magnan (2002) noted that SCM involves advanced information technologies, rapid and responsive logistics service, effective supplier management, and increasing customer relationship management. It is a managerial philosophy, the implementation of a managerial philosophy, and as a set of managerial process (McKeown, 2000). Managerial philosophy connotes SCM integrating the total flow of a distribution channel from suppliers to ultimate users (seeing the individual firms as integrated by common goals); implementation of a managerial philosophy extends integrated behaviour to incorporate customers and suppliers through external integration; and a set of managerial processes involves managing relationships, information, and material flows across enterprise borders to deliver enhanced customer service and economic values through synchronized management of the flow of physical goods and associated information from sourcing to consumption (McKeown, 2000; Chou et al, 2004).

The last being more encompassing was further improved by Mentzer et al (2001) and later by de Burca et al (2005). Mentzer et al viewed SCM as the systemic, strategic co-ordination of the traditional business functions within a particular company and across businesses within the supply chain, for the purpose of creating a sustainable competitive advantage (SCA) for the individual firms and the supply chain as a whole. Whereas de Burca et al (2005) saw it as the movement of products through the supply chain, the management of associated information flows and business relationships, and ultimately the creation of customer value. Ridgeway (1957) and McCammon and Little's (1965) likened SCM to Vertical Marketing System and operating system when they noted that the economic process, right from the acquisition of resources and running through manufacturing to the ultimate consumption, is a continuous process involving, in many cases, the economic flow of, and co-ordination of, activities of many independent firms.

The implication is Supply Chain Management (SCM) serves as the back-end application that links suppliers, manufacturers, distributors, and resellers in a cohesively collaborative production and distribution networks (Chou et al, 2004) that permit individual firms to exploit its unique competence fully and to outsource non-core activities from other channel members (Cox, 1999; Quinn, 2000), who perhaps possess superior capabilities. They are all independent firms working cohesively in collaboration with one another to form one extended system that must be administered as a whole rather than a part; decision by each sub-system/firm must be consistent and mutually supporting (Awa, 2003). The links involve moving products through the supply chain and creating customer values via effective management of information and relationships (de Burca et al, 2005). Thus the premise of SCM is profoundly based on the postulates of Relationship Marketing and Customer Relationship Marketing (CRM) that customer satisfaction or creating competitive advantage(s) does not depend solely on matching production to audiences' needs (JIT); rather it transcends to a great deal of other relationships with other corporate partners in the value chain (Boone and Kurtz, 2004). Previously and traditionally, relationship in supply chain focused on viewing suppliers and perhaps distributors as adversaries against 
whom to fiercely negotiate conditions and play one off games to shave margins. SCM has changed this awkward attitude as supposedly independent firms in the chain discovered the direct and/or indirect benefits of optimization in collaborative relationships (Cooper et al, 1997) perhaps subject to the harmonization of the interests of the individual firms.

\subsection{Internet Technology and SCM}

The Internet is a technological and business innovation with new methods of communications (Chellappa et al, 1996), business transactions (de Kare-Silver, 1998), market structure (Giaglis et al, 1999), education (Murison-Bowie, 1999), and work (Doukidis et al, 1998). Lai et al (2001) viewed Internet in SCM as an Inter-Organizational Information Systems (IOIS), which facilitates and enhances communications, transactions, productivity, and building of competitive advantages. It connotes digitalized networks connecting a business and its trading partners (e.g.; suppliers, dealers, customers, etc.) in ways to enhance operational effectiveness through out the value chain particularly with respect to real time information exchange and commercial transactions. Shuen (2008) opined that information sharing on the Web benefits business managers and industry analysts. The former can easily analyze internal business models to determine a company's or supply chain's profit engine; and the latter can compare a firm's performance relative to competitors and use that as a basis for assessing its stock market capitalization value, acquisition value, or total enterprise value. Exchange of information relates to the theory of bullwhip effects (Lee et al, 1997). Forrester's theory of bullwhip effects states that irregularities and unpredictability in order quantities increase with the number of layers in the chain and the implication is that access to demand data and supply capacity data within the supply chain makes for proactive and perhaps reactive responses to demand fluctuations. This bullwhip theory may not be wholly validated because collaborative relationship demands rationalization and consolidation of supply base (Matthyssens and Van den Builte, 1994) as reduction in number of suppliers or dealers will improve and deepen relationships (Humphreys et al, 2006). Reduction in the immediate supply chain leads to change in structure and the number of tiers in it. In manufacturing context, Humphreys et al (2006) observed that operationalizing this involves original equipment manufacturers (OEMs) buying up assembled systems or complete sub assemblies rather than individual components, thereby bringing another level into the supply chain. These policies permit first-tier suppliers to supply assembly systems and to co-ordinate the inputs and other activities of second-tier suppliers.

The Internet has revolutionized the supply chain (de Burca et al, 2005). Its strengths over EDI e.g.; ubiquitous and cost effective connectivity, speedy network transmission (Chou et al, 2004) and simplicity of use are well stimulated across the value chain (Davenport and Brook, 2004) to minimize conflicts (McCommon and Little 1965; Awa, 2003) and to enhance simultaneous improvement in customer service and network relationships (Kehoe and Boughton, 2001). eSCM manages information flows and represents a philosophy of managing technology and processes to optimize product delivery attributes, and information from suppliers through customers. An organization's Enterprise Resource Planning (ERP) must be integrated with CRM, e-procurement, and others, and implemented correctly before the advantages of eSCM capabilities can be fully exploited (Norris et al, 2001). Changes reflecting on management practices, performance standards, and business processes must be radically instituted in the entire supply chain to accommodate the new trend. Deloitte and Touche (1998) described Internet within the infrastructure of supply chain as an integral and one of the key drivers of change. Specifically, two major assets leading to the success of eSCM are often emphasized (Norris et al, 2001); they are viewing collaboration as a strategic and operational priority to foster trust (Morgan and Hunt, 1994), promise (Calonius, 1988), commitments (Dwyer et al, 1987), and mutuality (Czeipal, 1990) among trading partners; and management of information in the value chain with strict disciplines, policies, and monitoring.

The latter builds trusted relationship between parties and ultimately competitive advantage because the network effects of best practices are shared from the exchange of accurate and up-to-date information. The former viewed collaboration in terms of connoting some measure of social software involving mutual engagement and relationship building. It encompasses accessibility of internal activities and metrics by external parties (de Burca et al, 2005) as well as optimization of processes for mutual improvement in customer service, and reduction of inventory level and associated cost (Chou et al, 2004; Kehoe and Boughton, 2001); good business relationships built on trust and minimized selfishness even as perfect control over partners rarely exists (Scalet, 2001); and long term flexibility and adaptability evidenced by co-creation of products along the value chain (Sarkis and Sundarraj, 2000; van Hoek, 2001). The growth of e-commerce shifts decision power to buyers/users (Chou et al, 2004) and permits greater customization and user collaboration as well as faster organizational turnaround (Van Hoek, 2001), and ultimately improvement in relationships to build more customer loyal behaviour. Merono-Cerdan et al (2008) classified such collaborative tools into electronic communication systems (ECS) (e.g.; wikis and human-based computation) and teamwork system.

For instance, wiki is a metaphor for a new era of collaboration and participation (Tapscott and Williams, 2006) that encourages the entire supply chain accessing and editing websites; and human-based computation relates to technology that allows for collaborative problem solving within the supply chain (Cook, 2008). The ECS aims at facilitating information and opinion exchange, and enables relationships to be established among workgroups, customers, and 
institutions/supply chain members. The shared database updates information, keeps the organizations' systems memory up to date and prevents data from being repeated while being modified by authorized persons within the team or organization. The teamwork systems pre-define work processes and integrate information, which is classified into tworepositories and workflow. Repositories are important documents incorporating both unspoken and spoken knowledge in form of pictorial, textual and diagrammatic formats from project specialists; and workflow shows the sharing of the task among value chain members.

Porter (2001) opined that eSCM will build and deliver better sustainable competitive advantage (SCA) when strategically synchronized with such traditional sources as scale, human resources, and investments in physical assets, which also play prominent role. Knowledge management in eSCM system involves not technology alone but also its management by people. It espouses not only technology philosophies (ease-of-use, web-based, true multi-media, the use of broad-band, and mobile technologies) but also suggested behaviours (transparency, immediacy, participation, responsiveness, etc) (Mason et al, 2008; Coleman and Levine, 2008). eSMC is recognized for its characteristics of encouraging collaboration, knowledge sharing and management that culminate into enhanced productivity and building of long lasting inter-and intra-firm relationships, which ultimately reflect on customer satisfaction. It implies strategic alliance since integrated significant digital data generated through data-base marketing and relationship marketing may be archived and utilized successfully and collectively by an organization and its strategic/trading partners to build competitive advantage (Porter and Millar, 1985; Bibas, 1994; Gray and Watson, 1998).

\section{Methodology and Supply Chain Model}

In the light of the research agenda, authenticated information on current industry practice of SCM was based on case-study approach, involving the investigation of experience and knowledge of relevant industry managers, drawn across eight Port Harcourt-based indigenous organizations. This objective of this qualitative survey was to develop and report on the plausible broad-based view of how managers perceive the use of SCM as strategic for building competitive advantage. Specifically, the study unravelled whether the real perception of SCM varies across internal functions or inter-organizational positions in the channel structure. The cross-functions and inter-organizational characteristics of SCM signify boundary-spanning activity (Bowersox, 1999). Yin (1994) recognized case-study as an empirical inquiry, which investigates a contemporary phenomenon within its real life context when the boundaries between phenomenon and context are not clearly understood. In-depth interview(s) was conducted for more meaningful follow-up questioning and more extensive findings and insights.

The in-depth interviews lasted for 4 months and the target was 160 middle and senior level managers of purchasing, logistics, and manufacturing departments of the chosen organizations. The questions were structured and standardized to ensure uniformity. Where such positions do not exist in any of the chosen organizations, equivalents were used provided the occupants of such positions were directly involved in the implementation of SCM. The firms chosen for the study as reported in table 1 below are strategic in terms of being industry pace-setters and specifically they possess progressive reputation in supply chain practice. Literature review, pre-survey interviews, and advisory inputs from scholarly colleagues served to sharpen the survey instrument. The different sizes of the organizations informed the different number of respondents talked to. Only 108 (or 67.5 per cent) of the supposedly respondents actually held talks with the researchers; the rest, even when repeatedly visited were either not found on sit, too busy to attend to surveys, or inundated by surveys.

Figure 1 below presents a simplified model of supply chain integration as involving the independent firms and employees working collaboratively as one entity to achieve common goals of customer satisfaction and profitability. Often because of differences in tasks, the materials suppliers and service providers are managed differently in a co-ordinated manner perhaps by different functional areas of an organization. While managing materials suppliers is the responsibility of the purchasing department in most organizations, distribution and transportation (service providers) tasks are often handled by logistics, marketing, and perhaps purchasing departments. Except where streamlined standards exist and adhered to, this often breeds conflicts because each of these functional areas views organizational success, profitability and of course inter-and intra-organizational integration differently.

\section{Discussion}

The discussion of findings of this paper reflects the emerging nature of IT in Nigeria. Integrative attempts by firms surveyed loudly suggest some measure of substantive ambiguity and inconsistency over its meaning and actual practice because of varied functional views of SCM and of integrative nature. This supports Chou et al (2004), Kehoe and Boughton (2001), Deloitte and Touche (1998) and Fawcett and Magnan (2002). The organizations surveyed rated SCM on a seven-point scale and indicated it a critical strategy. For $\mathrm{O} 7$ and $\mathrm{O} 8$, the logistics managers are better disposed to integration and collaboration because they build a front-office system; purchasing managers are sceptical, back-office system, hesitant to integrative endeavours, and more comfortable with adversary practices, and the manufacturing managers appear on the fence, often responding more to the ideals of front-office than to back-office systems. Purchasing managers recognize SCM and eSCM as important competitive advantage building strategies but they are 
rarely sure of their ability to stand the tests of time. They (purchasing managers) trade price for traditional philosophy of non-collaborative behaviour perhaps because of the multiple relationships between a firm and its suppliers. Best suppliers may equally be suppliers to stiffest competitors, some suppliers may simultaneously serve as our competitors in other business areas, and sometimes it is difficult to enforce strict disciplines, policies, and monitoring conditions of Norris et al (2001) when key suppliers delay deliveries.

For O2, O3, O4, O5, and O6, the stock controller/manager, the ordering/purchasing officer, and the sales manager have similar understanding of SCM and eSCM. Though hampered by trading partners' and customers' readiness, especially other retailers, these firms view SCM and $\mathrm{SSCM}$ in terms of reducing inventory holding and ordering costs, and improving customer service and collaborative relationships. This finding validated previous studies (e.g.; Chan and Swatman, 2000; Davenport and Brooks, 2004; Raisch, 2001; de Burca et al, 2005). Despites these benefits of inter-organizational integration, this study identified internal cross functional process integration as the key of supply chain initiatives in the organizations surveyed. Backward integration with valued first-tier suppliers and forward integration with valued first-tier customers are the most common forms of supply chain integration (see the first two options in figure 2 below. Downward and upward streams integration (see option three), though recorded by authorities as being practised by few firms, was never practised by the firms surveyed. Finally, complete forward and backward integration (the last option), expressed from suppliers' supplier to consumers' to consumers, is more of theoretical framework.

Asking the respondents to identify any of these types of integration in relation to their extent of use by their employers, it was revealed that organizations prefer internal cross-functional integration to inter-organizational integration. Fawcett and Magnan (2002) validated this with the clause of difficulties of tackling issues as aligning measures, meshing information systems, and sharing risks and rewards. Function-to-function interactions produce the least conflicts in the value chain. Agrawal and Pak (2001) attributed firms' resistance to information sharing across the value chain to using it to build unique competitive edge. Resistance to information sharing contrasts the view that eSCM provides opportunities that are largely unexploited (Ramdani et al, 2009); particularly it offers small firms plausible ways to strengthen competitive capability against their larger counterparts (Gengatharen and Standing, 2005; Urwin, 2000; Raymond, 2001). For inter-organizational integration, forward integration is operated more than backward integration and complete integration rarely operates. Logisticians are more concerned with customer satisfaction (front-face), which often attracts more of top management's interests than the purchasers' back-face systems.

All the organizations studied are at the preliminary stage of their inter-organizational collaborative relationships given the emerging nature of IT in Nigeria; each firm is at different stages in the journey, evidencing that the firms surveyed strongly know about the strategic implications of such integration. The major barrier to investment in collaborative integration is that of harmonizing the interests of front-face and back-face systems.

\section{Conclusions and Managerial Implications}

The world is now a global village and perhaps, less predictable. This is predominantly evidenced in the mode of business operations, which have vastly changed in favour of firms that are strategic and entrepreneurial in embracing the changing trends. Synchronizing SCM with IT is a welcome development for building inter-and intra-organizational cohesive teams that operate to compete across borders to increase productivity and market share amidst globalization, technological break-through, customer dynamism, competition, and other environmental demands. Several operations-based models (e.g.; Just in Time, Business Process Re-engineering, Total Quality Management, etc) have recently flooded the business environment, many of which have no staying power. Today SCM is smoke-balled a better model responsible for inter-and intra-organizational alliance in the supply chain though its actual practice is at variance with its theoretical frameworks. Its purpose is to optimize performance and competitive advantage in the value chain subject to having the broad-based mindset and the underlying collaborative infrastructures. The practice of SCM demands a set of fundamental criteria such as optimized collaborative relationship, inter-organizational processes, organizational structure, shared risks and rewards, aligned objectives and goals, consistent measurement metrics, and corporate cultures. These building blocks must be assessed, harmonized and aligned to form an integrative strategy that will be mutually benefiting. SCM as a social platform and/or a social system directs that once a sub-system is weak, the entire whole becomes weak. Having a profile page on the sites and linking online with other chain members for reasons of accessing their operations, eSCM permits proactive and perhaps, reactive handling of problems.

Authenticated and real time information capabilities deliver significant improvements in productivity and responsiveness in the supply chain and above all customer satisfaction and retention. The practice of collaborative alliance transcends information sharing and exchange to include information co-ordination to ensure their real time use in supply chain decision-making. SCM and of course eSCM have their staying power yet to be confirmed for it may be difficult to believe that one day competition against rivals will disappear and competition between supply chains for market supremacy fills the vacuum. Firms form vertical integration team that competes across boundaries in attempts to improve network effects and ultimately to capture larger global market share. The ideals of SCM appear seemingly 
fascinating and rosy perhaps because it is a paradigm shift from selfishness to mutually consistent operations but in actual practice, much tension exists between SCMs' competitive potential and the inherent difficulty of collaboration, especially in the area of inter-organizational collaboration. Internal cross-functional, function-to-function, and front-face integrative relationships are more adopted and sometimes traditional non-collaborative philosophy still obtains. Supply chain is rarely managed from suppliers' supplier to customers' customer; and even among great users of SCM, integration spans a triad of companies, involving the company and one-tier up (front-office) and one-tier down (back-office) streams.

Lack of perceptual commonality besieges SCM and multiple supply chain collaborations often complicate supply chain design and management because boundaries and specifics of relationships may be vaguely defined. Differences exist in the front-office and back-office systems. The front-office enjoys somewhat measure of collaboration and integration because of its huge interest in building customer satisfaction and the back-office believes more in non-collaborative moves with suppliers.

Based on our findings, the following recommendations appear to encourage more successful applications by the firms surveyed and related ones.

- Harmonization need be done and everything spelt out before hand to avoid conflicts in the value chain.

- $\quad$ Precise and all encompassing formal definition of SCM as well as metrics of focus and measurement should be thought out and visibly posted and communicated through out the value chain to ensure balance between theory and practice.

- $\quad$ Trust and mutuality should be built into the value chain and a broad-based mindset developed to show commitment to the underlying collaborative infrastructures of SCM in an effort to guarantee its staying power.

- $\quad$ The front-office and back-office systems focus on customers and suppliers respectively and each has different views about SCM. Handling the doubts of front-office system and integrating and harmonizing its philosophies with those of back-office system will improve the adoption and results of SCM.

- A balanced behaviour by manufacturing manager will undoubtedly encourage more inter-organizational collaborative relationship.

\section{References}

Abell, D. (1999). Competing today while preparing for tomorrow. Sloan Management Review, 40(3), 73-81.

Agrawal, M. \& Pak, M. (2001). Getting Smart about Supply Chain Management. The McKinsey Quarterly, 2, 22-27.

Awa, H. (2003). Modern Marketing Theory: An Integrated Approach to Managerial Decisions. Owerri: Kolleey Publishers.

Ballou, R; Stephen, M; \& Mukherjee, A. (2000). New Managerial Challenges from Supply Chain Opportunities. Industrial Marketing Management, 29(1), 7-18.

Bartholomew, D. (1999). What's Really driving Apple's Recovery? Industry Week, 15(March), 34-40.

Bibas, S. (1994). A Contractual Approach to Data Privacy. Harvard Journal of Law \& Public Policy, 17(2), 591-622.

Blackwell, R. (1997). From Mind to Market: Reinventing the Retail Supply Chain. New York: Harper Business.

Boone, L. \& Kurtz, D. (2004). Contemporary Marketing $11^{\text {th }}$ ed. Ohio, USA: South-Western.

Bowersox, D; Closs, D; \& Stank, T. (1999). 21 ${ }^{\text {st }}$ Century Logistics: Making Supply Chain Integration a Reality. Council of Logistics Management, Oak Brook 11.

Brown, D. \& Kaewkitipong, L. (2009). Relative Size and Complexity: E-Business Use in Small and Medium Sized Tourism Enterprises in Thailand. Journal of Enterprise Information Management, 22(1/2), 212-231.

Brown, D. \& Lockett, N. (2004). Potential of Critical E-Applications for Engaging SMEs in E-Business: A Provider Prospective. European Journal of Information Systems, 13(1), 21-34.

Buchanan, R. \& Gilles, C. (1990). Value Managed Relationships: The Key to Customer Retention and Profitability. European Journal of Management 8(4), 205-215.

Buonanno, G; Faverio, P; Pigni, F; Ravarini, A; Sciuto, D; \& Tagliavini, M. (2005). Factors affecting ERP Systems Adoption: A Comparative Analysis between SMEs and large companies. Journal of Enterprise Information Management. 18(4), 384-426.

Calonius, H. (1988). A Buying Process Model in Innovative Marketing: An European Perspective. Proceedings of the XVIIthe Annual Conference of the European Marketing Academy. Blois, K. \& Parkinson, S. (ed.), University of Bradford, 86-103. 
Chan, C. \& Swatman, P. (2000). From EDI to Internet Commerce: The BHP Steel Experience. Internet Research-Electronic Networking Applications \& Policy, 10(1), 72-82.

Chellappa, R; Barua, A; \& Whinston, A. (1996). Looking beyond Internal Corporate Web Server. In Kalakota, R. \&Whinston, A. (eds). Readings in Electronic Commerce. Reading, MA: Addison-Wesley.

Chou, D; Tan, X; \& Yen, D. (2004). Web Technology and Supply Chain Management. Information Management and Computer Security, 12(4), 338-349.

Chuang, T; Rutherford, M. \& Lin, B. (2007). Owner/Manager Characteristics, Organizational Characteristics and IT Adoption in the SMEs, Journal of Management \& Enterprise Development, 4(6), 619-634.

Chuang, T; Nakatani, K; \& Zhou D. (2009). An Exploratory Study of the Extent of Information Technology Adoption in SMEs: An Application of Upper Echelon Theory. Journal of Enterprise Information Management, 22(1/2), 183-196.

Cook, N. (2008). Enterprise 2.0: How Social Software will Change Future of Work. Farnham Gower Publishing Ltd.

Cooper, M; Lambert, D; \& Pagh, J. (1997). Supply Chain Management: More than aNew Name for Logistics. The International Journal of Logistics Management, 8(1), 1-14.

Cottrill, K. (1997). The Supply Chain of the Future. Distribution, 96(11), 52-54.

Cox, A. (1999). Power, Value and Supply Chain Management. Supply Chain Management: An International Journal, 4(4), 167-175.

Czeipal, J. (1990). Service Encounters and Service Relationships: Implications for Research. Journal of Business Research, 20, 13-21.

Dabholkar, P. (1992). The Role of Prior Behaviour and Category-based Affect in On-site Service Consumers. In Sherry, T. \& Sternthal, B. (eds.) Diversity in Consumer Behaviour. Association for Consumer Research, Provo, UT. 563-569.

Davenpart, T. \& Brooks, J. (2004). Enterprise Systems and the Supply Chain. Journal of Enterprise Information Management, 17(1), 8-19.

de Burca, S; Fynes, B; \& Marshall, D. (2005). Strategic Technology Adoption: Extending ERP Across the Supply Chain. Journal of Enterprise Information Management, 18(4), 427-440.

de Kare-Silver, M. (1998). E-Shock: The Electronic Shopping Revolution: Strategies for Retailers and Manufacturers. Basingstoke: Palgrave Macmillian.

Dell, M. \& Fredman, C. (1999). Direct from Dell: Strategies that Revolutionized an Industry. New York: Harper Business.

Deloitte and Touche (1998). 1998 Vision in Manufacturing (Global Report). Global Manufacturing Survey by Deloitte and Touche \& Deloitte Consulting.

Dixon, D. (2004). The Truce between Lean and IT. Industrial Engineer, 36(6), 42-45.

Doukidis, G; Poulymenakou, A; Terpsidis, I; Themisticleous, M; \& Miliotis, P. (1998). The Impact of the Development of Electronic Commerce on the Employment Situation in European Commerce, Athens University of Economics and Business, Athens.

Du, L. (2007). Acquiring Competitive Advantage in Industry through Supply Chain Integration: A Case Study of Yue Yuen Industrial Holdings Ltd; Journal of Enterprise Information Management, 20(5), 527-543.

Dyer, J. (1996). Specialized Supplier Networks as a Source of Competitive Advantage: Evidence from the Auto Industry. Strategic Management Journal, 17(4), 271-291.

Esteves, J. (2009). A Benefits Realization Road-Map Framework for ERP Usage in Small and Medium-Sized Enterprises. Journal of Enterprise Information Management, 22(1/2), 25-35.

Fawcett, S. \& Magnan, G. (2002). The Rhetoric and Reality of Supply Chain Integration. International Journal of Physical Distribution \&Logistics, 32(5), 339-361.

Federici, T. (2009). Factors Influencing ERP Outcomes in SMEs: A Post-Introduction Assessment. Journal of Enterprise Information Management, 22(1/2), 81-98.

Ferguson, B. (2000). Implementing Supply Chain Management. Production and Inventory Management Journal, 2(2), 64-67.

Fernie, J. (1995). International Comparisons of Supply Chain Management in Grocery Retailing. Service Industries Journal, 15(4), 134-147

Filley, A; House, R; \& Kerr, S. (1971). Relation of Leader Consideration andInitiating Structure to R \& D Subordinates' Satisfaction. Administrative Science Quarterly, 6, 19-30. 
Fillis, I; Johanson, U; \& Wagner, B. (2003). A Conceptualization of the Opportunities and Barriers to E-Business Development in the Small Firms. Journal of Small Business and Enterprise Development, 10(1), 336-344.

Forrester, J. (1958). Industrial Dynamics: A Major Breakthrough for Decision-Makers. Harvard Business Review, July-August, 37-66.

Frechlich, G; Hoover, H; Liew, W. \& Sorenson, P. (1999). Application Framework Issues when evolving Business Applications of Electronic Commerce, Information Systems, 24(6), 457-473.

Giaglis, G; Klein, S; \& O’Keefe, R. (1999). Disintermediation, Reintermediation, or Cybermediation? The Future of Intermediaries in Electronic Marketplace.

Handfield, R. \& Nichols, E. (1999). Introduction to Supply Chain Management. Prentice-Hall, Englewood Cliffs, New Jersey.

Hewitt, F. (1999). Information Technology mediated Business Process Management: Lesson from the Supply Chain. International Journal of Technology Management. 17(1/2), 37-53.

Humphreys, P; Mclvor, R; \& Cadden, T. (2006). B2B Commerce and its Implications for the Buyer-Supplier Interface. Supply Chain Management: An International Journal. 11(2), 131-139.

Gengatharen, D. \& Standing, C. (2005). A Framework to assess the Factors Affecting Success or Failure of the Implementation of Government-Supported Regional E-Marketplaces for SMEs. European Journal of Information Systems, 14, 417-433.

Gray, P. \& Watson, H. (1998). Decision Support in the Data Warehouse. A Simeon \& Schuster Co; Englewood Cliffs, New Jersey: Prentice-Hall.

Johnston, R. \& Mak, H. (2000). An Emerging Vision of Internet-enabled Supply Chain Electronic Commerce. International Journal of Electronic Commerce, 4(4), 43-59.

Kaplan, S. \& Sawhney, M. (2000). E-Hubs: The New B2B Marketplaces. Harvard Business Review, 78(3), 97-103.

Kehoe, D. \& Boughton, N. (2001). New Paradigms in Planning and Control Across Manufacturing Supply Chains: The Utilization of Internet Technologies. International Journal of Operations \& Production Management, 21(5/6), 582-593.

Kennerley, S. \& Neely, B. (2001). Enterprise Resource Planning: Analyzing the Impact. Integrated Manufacturing Systems, 12(2), 103-113.

Koch, C. (2001). ERP and ERP: Realizing a Vision of Process with IT. Business Process Management Journal, 7(3), 285-296.

Kowath, N. \& Choon, T. (2001). Determinants of Website Development: A Study of Electronic Commerce in Singapore. Information \& Management, 39(3), 227-242.

Lai, M; Humphreys, P. \& Sculli, D. (2001). The Implications of Western Electronic Commerce for Chinese Business Networks. Industrial Management \& Data Systems, 101(6), 281-289.

Lee, H; Padmanabhan, V; \& Whang, S. (1997). Information Distortion in a Supply Chain: The Bullwhip Effect. Management Science, 43(4), 546-558.

Mason C; Castleman, T. \& Parker, C. (2008). Communities of Enterprise: Developing Regional SMEs in Knowledge economy. Journal of Enterprise Information Management, 21(6), 571-584.

Matthyssens, P. \& Van den Builte, C. (1994). Getting Closer and Nicer: Partnership in the Supply Chain. Long Range Planning, 27(1), 72-83.

McAfee, A. (2006). Enterprise 2.0: The Dawn of Emergent Collaboration. MIT Slogan Management Review, 47(3), 21-28.

McCommon, B. \& Little, R. (1965). Marketing Channels: Analytical Systems and Approaches. In Schwartz, G. (ed).Science in Marketing. John Wiley \& Sons, Inc; New York.

McKeown, P. (2000). Information Technology and the Networked Economy. Boston, M.A: Course Technology Publishing.

Mentzer, J; DeWitt, W; Keebler, J; Min, S; Nix, N; Smith, C; \& Zacharia, Z. (2001) Defining Supply Chain Management. Journal of Business Logistics, 22(1), 1-25.

Merono-Cerdan A. L., Soto -Acosta P. \& Lopez Nicolas C. (2008). Analysing Collaborative Technologies Effect on Performance through Internet Use Orientations. Journal of Enterprise Information Management, 21(1), 39-51.

Morgan, R. \& Hunt, S. (1994). The Commitment-Trust Theory of Relationship Marketing. Journal of Marketing, 58(July), 20-38. 
Murison-Bowie, S. (1999). Forms and Functions of Digital Content in Education. In Leer, A. (ed). Masters of the Wired World. London: Financial Times, Pitman Publishing.

Norris, G; Hurley, J; Hartley, K; \& Dunleavy, J. (2001). E-Business and ERP: Transforming the Enterprise. London: John Wiley.

Power, D. \& Sohal, A. (2002). Implementation and Usage of Electronic Commerce in Managing the Supply Chain: A Comparative Study of Ten Australian Companies. Benchmarking: An International Journal, 9(2 ), 190-208.

Porter, M. (2001). Strategy and the Internet. Harvard Business Review, 79(2), 63-78.

Porter, M. \& Millar, V. (1985). How Information gives you Competitive Advantage. Harvard Business Review, 63(4). 149-160.

Quinn, F. (2000). The Clock-speed Chronicles. Supply Chain Management Review, 3(4), 60-64.

Raisch, W. (2001). The E-Marketplace: Strategies for Success in B2B E-Commerce. New York: McGraw-Hill.

Ramdani, B; Kawalek, P; \& Lorenzo, O. (2009). Knowledge Management and Enterprise Systems Adoption by SMEs: Predicting SMEs' Adoption of Enterprise Systems. Journal of Enterprise Information Management, 22(1/2), 10-24.

Ridgeway, V. (1957). Administration of Manufacturer-Dealer Systems. Administration Science Quarterly. March, 464-467.

Sarkis, J. \& Sundarraj, R. (2000). Factors for Strategic Evaluation of Enterprise Information Technologies. International Journal of Physical Distribution \& Logistics Management, 30(3/4), 196-220.

Scalet, S. (2001). The Cost of Secrecy. CIO Magazine, July, www.cio.com.

Shiau, W; Hsu P; \& Wang, J (2009). Development of Measures to Assess the ERP Adoption of Small and Medium Enterprises. Journal of Enterprise Information Management. 22(1/2), 99-118.

Shuen, A. (2008). Web 2.0: A Strategic Guide. First Edition, Sebastopol: O’ Reilly Media, Inc.

Tapscott, D. \& Williams, A. (2006). Wikinomics: How Mass Collaboration Changes Everything. New York: Portfolio. Businesses. Journal of Management Information Systems. 15(4), 27-31

Van Hoek, S. (2001). E-Supply Chains-Virtually Non-Existing. Supply Chain Management: An International Journal, 6(1), 21-28.

Walton, S. \& Gupta, J. (1995). Electronic Data Interchange for Process Change in an Integrated Supply Chain. International Journal of Operations and Production Management, 19(4), 372-388.

Wood, A. (1997). Extending the Supply Chain: Strengthening Links with IT. Chemical Week. 159(25), 26.

Yin, R. (1994). Case Study Research: Design and Methods. Newbury Park, CA: Sage Publications.

Table 1. Sample Size and Response rates

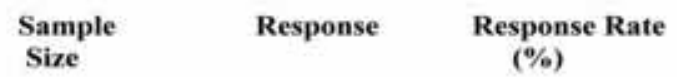

\begin{tabular}{|c|c|c|c|}
\hline $\begin{array}{l}\text { Oil Tools } \\
\text { Retailers: } \\
\text { 1. Kaycee \& }\end{array}$ & & & \\
\hline Sons Ltd. & 27 & 15 & 55.6 \\
\hline 2. Ghani Int'1. & 23 & 17 & 73.9 \\
\hline Superstores: & & & \\
\hline $\begin{array}{l}\text { 3. Spot One } \\
\text { 4. Everyday }\end{array}$ & 20 & 16 & 80.0 \\
\hline Supermarket & 25 & 18 & 72.0 \\
\hline $\begin{array}{l}\text { Electronics \& } \\
\text { Home Appli.: }\end{array}$ & & & \\
\hline $\begin{array}{l}\text { 5. Value City } \\
\text { Electrical } \\
\text { 6. Obiekwe }\end{array}$ & 15 & 9 & 60.0 \\
\hline Electrical & 15 & 7 & 46.7 \\
\hline $\begin{array}{l}\text { Bakery Firms: } \\
\text { 7. Tea-Mate }\end{array}$ & & & \\
\hline $\begin{array}{l}\text { Bread } \\
\text { 8. }\end{array}$ & 18 & 12 & 66.7 \\
\hline Bread & 17 & 14 & 82.4 \\
\hline Total & 160 & 108 & \\
\hline
\end{tabular}




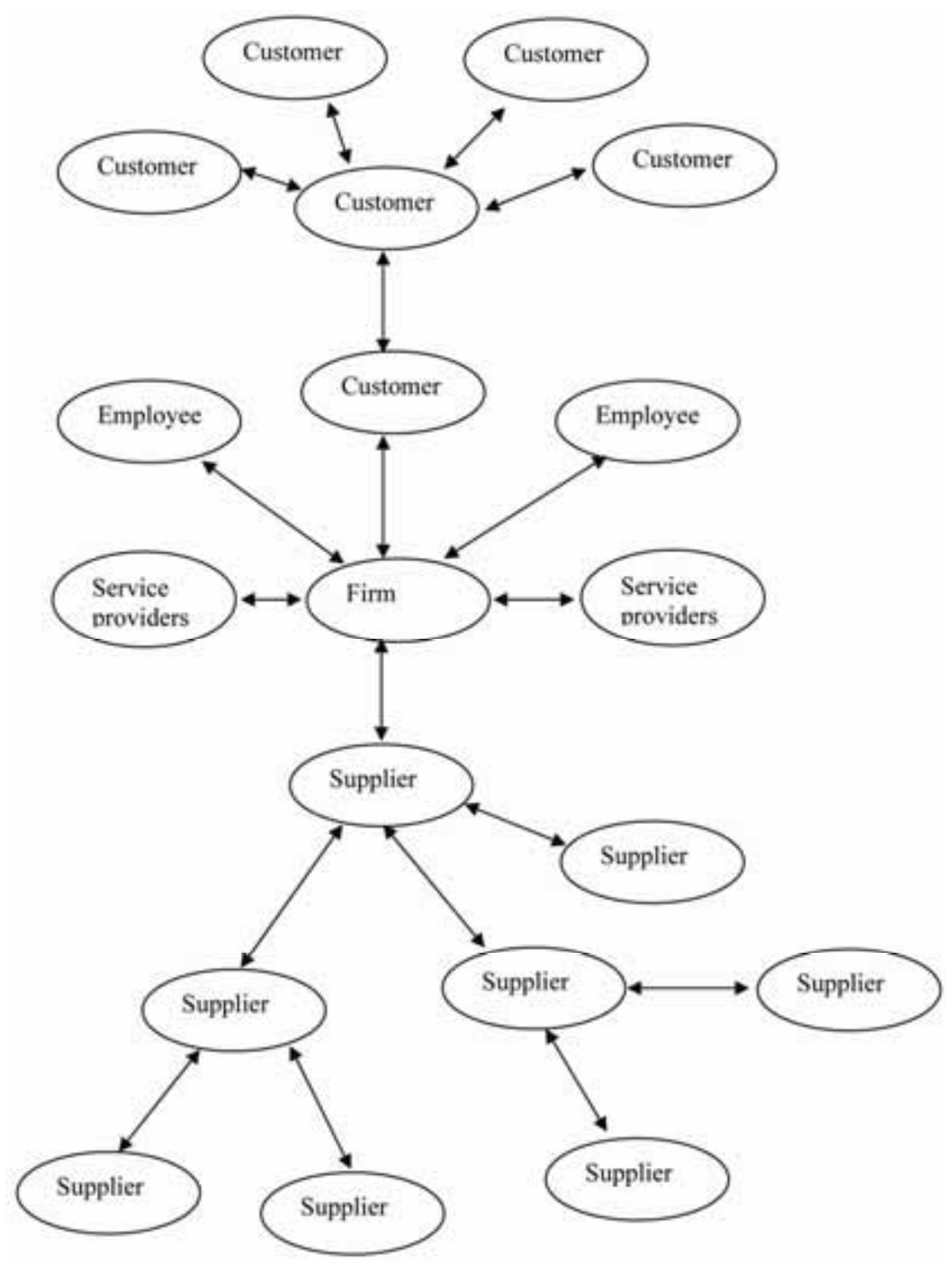

Figure 1. Model of Relationship in Supply Chain

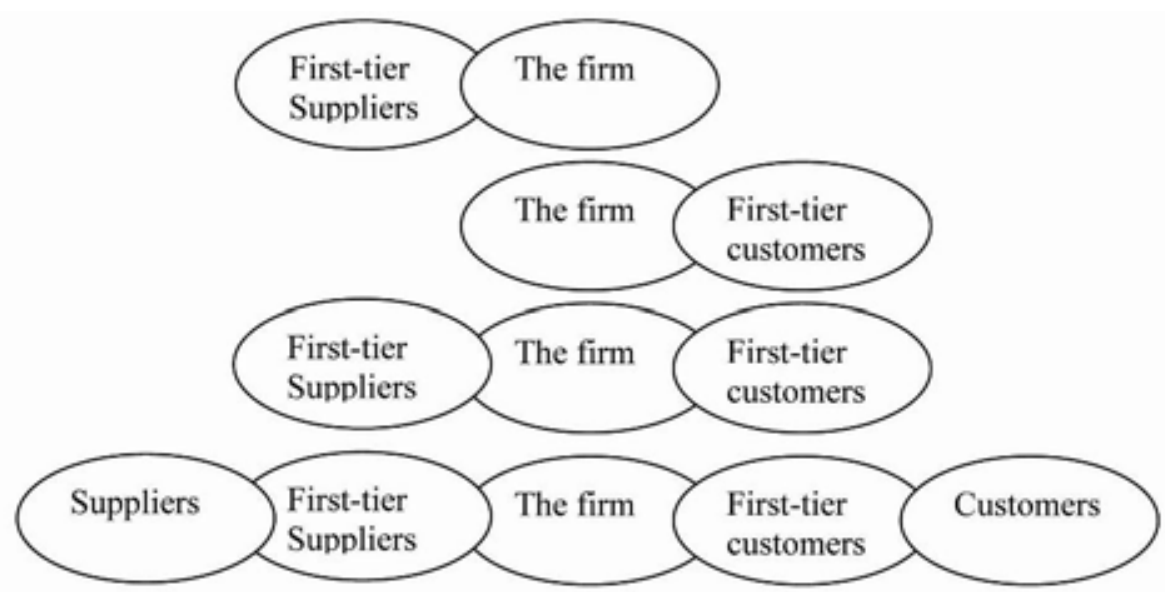

Figure 2. Strategic options in supply chain indicating the status of integration 